\title{
ЗАПРЕТ ОПРЕДЕЛЕННЫХ ДЕЙСТВИЙ - АЛЬТЕРНАТИВНАЯ МЕРА ПРЕСЕЧЕНИЯ В УПК РФ
}

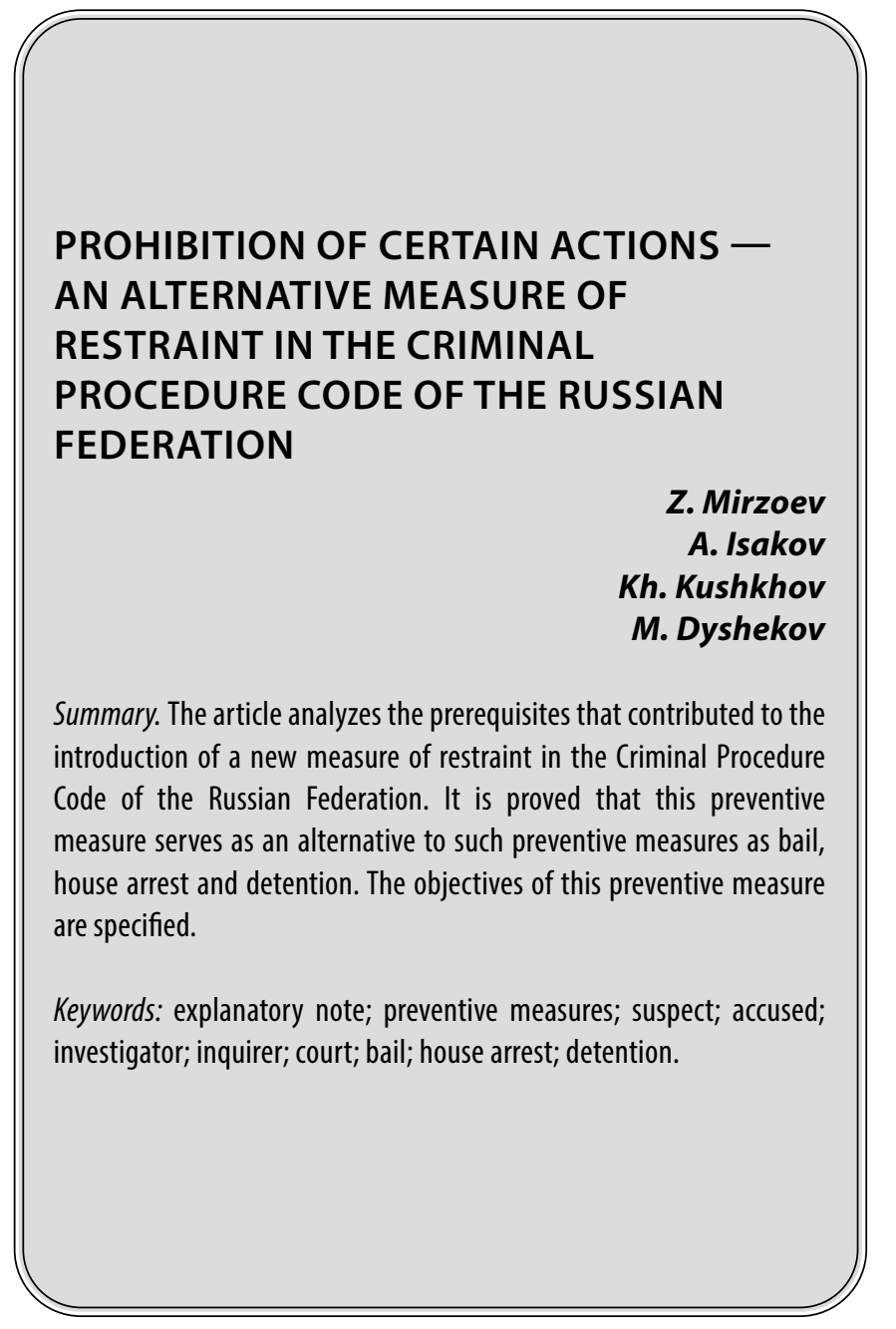

B Уголовно-процессуальный кодекс Российской Федерации Федеральным законом от 18 апреля 2018 г. № 72-Ф3 внесены изменения. Глава 13 «Меры пресечения» претерпела изменения. Появилась новая мера пресечения «Запрет определенных действий» ст. 105.1. В связи с введением данной меры пресечения, в УПК РФ были внесены изменения в следующие статьи УПК РФ: 98 «Меры пресечения»; 106 «Залог»; 107 «Домашний арест». Внедрению в УПК РФ новой меры пресечения в виде запрета определенных действий предшествовала пояснительная записка «К проекту Федерального закона «О внесении изменений в Уголовно-процессуальный кодекс Российской Федерации (в части избрания и применения мер пресечения в виде залога, запрета определенных действий и домашнего ареста [1])».
Мирзоев Залим Таубиевич

Старший преподаватель, Кабардино-Балкарский государственный университет им. Х.М. Бербекова

(Нальчик)

trapik80@mail.ru

Исаков Аслан Русланович

К.ю.н., дочент, Кабардино-Балкарский государственный университет им. Х.М. Бербекова (Нальчик)

isaslan@mail.ru

Куихов Хажмурат Леонович

Старший преподаватель, Кабардино-Балкарский государственный университет им. Х.М. Бербекова

(Нальчик)

khajmurat@yandex.ru

Дышеков Мурат Владимирович

К.и.н., дочент, Кабардино-Балкарский государственный университет им. Х.М. Бербекова

(Нальчик)

dugur1@mail.ru

Аннотация. В статье анализируются предпосылки, которые способствовали введению новой меры пресечения в УПК РФ. Обосновывается, что данная мера пресечения служит альтернативой, таким мерам пресечения как залог, домашний арест и заключение под стражу. Указываются цели данной меры пресечения.

Ключевые слова: пояснительная записка; меры пресечения; подозреваемый; обвиняемый; следователь; дознаватель; суд; залог; домашний арест; заключение под стражу.

Анализируя положения, указанные в данной пояснительной записке, можно сделать некоторые выводы, обосновывающие необходимость введения новой меры пресечения в УПК РФ. Законодатель указывает на то, что данная мера пресечения служит альтернативой, такой мере пресечения как заключение под стражу в отношении лиц подозреваемых и обвиняемых в совершении преступления, а также способствует обеспечению прав личности, исполнению общепризнанных международных норм права, повышению эффективности уголовного преследования, экономии средств федерального бюджета.

Также в пояснительной записке указывается, что в 2008 году на VII Всероссийском съезде судей был задан курс на диверсификацию системы мер пресечения, в рам- 
ках которой было принято решение о необходимости дальнейшей оптимизации мер пресечения, не связанных с изоляцией от общества, в том числе залога и домашнего ареста. Такое решение обосновывалось тем, что ранее внесенные изменения в УПК РФ, в части касающейся мер пресечения, а именно, появление таких мер пресечения как залог и домашний арест не привели к ожидаемым результатам и не стали реальной альтернативой такой мере пресечения как заключение под стражу.

Необходимо признать, что во многих случаях, суд, удовлетворяя ходатайство о применении к лицу подозреваемому, обвиняемому в совершении преступления меры пресечения в виде заключения под стражу, руководствуется тем, что ни залог, ни домашний арест не будут достаточно эффективными по отношению к конкретному лицу.

Основания для избрания меры пресечения прописаны в ст. 97 УПК РФ [2].

Дознаватель, следователь, а также суд в пределах предоставленных им полномочий вправе избрать подозреваемому, обвиняемому одну из мер пресечения, предусмотренных УПК РФ, при наличии достаточных оснований полагать, что обвиняемый, подозреваемый:

1. скроется от дознания, предварительного следствия или суда;

2. может продолжать заниматься преступной деятельностью;

3. может угрожать свидетелю, иным участникам уголовного судопроизводства, уничтожить доказательства либо иным путем воспрепятствовать производству по уголовному делу.

Анализируя ст. 105.1 УПК РФ запрет определенных действий, можно предположить, что законодатель усмотрел некую пробельность в перечне мер пресечения, которая заключалась в том, что на практике, применение к подозреваемому, обвиняемому такой меры пресечения, как подписка о невыезде является не достаточно действенной, а залог, домашний арест или заключение под стражу являются чрезмерно суровыми.

В связи с чем, было принято решение ввести в действующее уголовно-процессуальное законодательство, некую пограничную меру пресечения «Запрет определенных действий». При этом, в статье ст. 105.1 УПК РФ указывается, что данная мера пресечения избирается в отношении подозреваемого или обвиняемого при невозможности применения иной, более мягкой, меры пресечения.

Так как данная мера пресечения подразумевает под собой, ограничение конституционных прав и свобод человека и гражданина, для ее применения предусмотрено получение судебного решения. При этом, лицо ведущее производство по уголовному делу, а именно, следователь обязан получить согласие руководителя следственного органа, а дознаватель согласие прокурора для возбуждения соответствующего ходатайства перед судом. В постановлении о возбуждении перед судом данного ходатайства, следователь, дознаватель указывают, какие именно ограничения предусмотренные ч. 6 ст. 105.1 УПК РФ они считают необходимыми для применения к конкретному подозреваемому, обвиняемому и обосновывают свою позицию.

Применение данной меры пресечения преследует две цели. Первая цель заключается в своевременной явке подозреваемого, обвиняемого по вызову дознавателя, следователя или в суд. Вторая цель направлена соблюдение запрета (запретов), возложенных судом на подозреваемого или обвиняемого.

В соответствии с ч. 2 ст. 105.1 УПК РФ данную меру пресечения можно применить к любому подозреваемому, обвиняемому по уголовному делу, независимо от тяжести совершенного преступления и его возраста. Таким образом, законодатель предоставляет выбор должностным лицам органов уголовного преследования и суду, какую именно меру пресечения необходимо применить к подозреваемому, обвиняемому. При этом суд должен учитывать данные о личности подозреваемого или обвиняемого, а также фактические обстоятельства уголовного дела при принятии решения, какой именно запрет или какие именно запреты необходимо применить к лицу, подозреваемому или обвиняемому по уголовному делу.

Суд при избрании меры пресечения в виде запрета определенных действий может возложить следующие запреты, предусмотренные ч. 6 ст. 105.1 УПК РФ:

1. выходить в определенные периоды времени за пределы жилого помещения, в котором он проживает в качестве собственника, нанимателя либо на иных законных основаниях;

2. находиться в определенных местах, а также ближе установленного расстояния до определенных объектов, посещать определенные мероприятия и участвовать в них;

3. общаться с определенными лицами;

4. отправлять и получать почтово-телеграфные отправления;

5. использовать средства связи и информационно-телекоммуникационную сеть «Интернет»;

6. управлять автомобилем или иным транспортным средством, если совершенное преступление связано с нарушением правил дорожного движения и эксплуатации транспортных средств. 
Подозреваемый или обвиняемый, может быть, подвергнут судом всем запретам, указанным в ч. 6 ст. 105.1 УПК РФ либо некоторым из них.

Перечень запретов не подлежит расширительному толкованию. Такой подход представляется верным, поскольку позволяет исключить произвол правоприменителя при избрании меры пресечения, что будет неизбежно в случае реализации высказанных отдельными исследователями противоположных предложений [3].

Подводя итог исследованию, хотелось бы сделать некоторые выводы.

При решении вопроса об избрании конкретной меры пресечения, в том числе и запрета определенных действий, суду необходимо руководствоваться обстоятельствами, изложенными в ст. 97 УПК РФ. Появление новой меры пресечения в виде запрета определенных действий служит альтернативой таким мерам пресечения как залог, домашний арест и заключение под стражу, что, по нашему мнению, является позитивным нововведением в УПК РФ.

Также применение данной меры пресечения влечет экономию средств федерального бюджета, а так- же уменьшения сумм выплат в счет возмещения вреда за нарушение прав личности при заключении под стражу.

Появление данной меры пресечения, предполагающей возможность подозреваемому, обвиняемому оставаться по месту своего проживания, хотя и с определенными запретами, установленными судом, несомненно, является составляющим элементом взятого курса направленного на гуманизацию российского законодательства.

По нашему мнению, на практике, с учетом данных о личности подозреваемого или обвиняемого, а также фактических обстоятельств уголовного дела необходимо достаточно интенсивно применять новую меру пресечения. При этом, руководствоваться тем, что запрет определенных действий может быть изменен на более строгую меру пресечения по следующим основаниям:

- нарушение обвиняемым возложенных запретов;

- отказ обвиняемого от применения технических средств контроля;

- умышленное повреждение, уничтожение или нарушение функционирования обвиняемым технических средств контроля [4].

\section{ЛИТЕРАТУРА}

1. Пояснительная записка к проекту Федерального закона «0 внесении изменений в Уголовно-процессуальный кодекс Российской Федерации (в части избрания и применения мер пресечения в виде залога, запрета определенных действий и домашнего ареста») // http://asozd.duma.gov.ru.

2. «Уголовно-процессуальный кодекс Российской Федерации» от 18.12.2001 № 174-Ф3 (ред. от 30.04.2021) // http://pravo.gov.ru.

3. Овчинников Ю.Г. Домашний арест как мера пресечения в уголовном процессе: Дис. ... канд. юрид. наук. Омск, 2006. С. 87.

4. Стельмах В.Ю. Мера пресечения «запрет определенных действий» // Российский следователь. 2020. № 2. С. 25.

( ) Мирзоев Залим Таубиевич ( trapik80@mail.ru ), Исаков Аслан Русланович ( isaslan@mail.ru ), Кушхов Хажмурат Леонович ( khajmurat@yandex.ru ), Дышеков Мурат Владимирович ( dugur1@mail.ru ). Журнал «Современная наука: актуальные проблемы теории и практики» 